\title{
Immobilis ideák vs. mobil kommunikáció
}

„A 21. század kommunikációja” címủ projekt legújabb kötetéről

E könyvismertető a mobil kommunikáció tárgyában Magyarországon legutóbb megjelent, Nyíri Kristóf szerkesztette könyvvel foglalkozik. A kötet egy hétéves, számos nemzetközi konferenciával és előző kötettel büszkélkedő kutatási program fő eredményeit összegzi. A recenzió szerzője a műfaj hagyományaihoz híven a kötet valamennyi tanulmányát megemlíti, és a projektnek azokat a filozófiai aspektusait hangsúlyozza, amelyeket az iskolafilozófusok gyakran megkérdőjeleznek.

Kulcsszavak: mobil kommunikáció, információs társadalom, filozófia, társadalom-tudományok

\section{Szerzői információ:}

Danka István

Filozófus, a Pécsi Tudományegyetemen és a müncheni Ludwig-Maximilian Egyetemen végezte tanulmányait, jelenleg a Leedsi Egyetem filozófiai doktori iskolájának ösztöndíjas hallgatója. Fő kutatási témája a filozófia szerepe a felsôoktatásban az elektronikus kommunikáció korában. Posztgraduális tanulmányokat és kutatásokat Pécsett, Bécsben és a bergeni Wittgenstein Archívumban folytatott. 2001 és 2006 között az MTA Filozófiai Kutatóintézetének tudományos segédmunkatársa volt. 2002 és 2004 között szemináriumokat tartott a Pécsi Tudományegyetem filozófia szakán, majd az ELTE Eötvös Collegiumában. Számos nemzetközi és hazai konferencián szerepelt elóadóként, publikációi Wittgensteinról, valamint a nyelvfilozófia, az ismeretelmélet, a kommunikációfilozófia és a pragmatizmus témaköreiben jelentek meg magyar és angol nyelven. E-mail: danka.istvan@gmail.com

Így hivatkozzon erre a cikkre:

Danka István. „Immobilis ideák vs. mobil kommunikáció”.

Információs Társadalom VII, 3. szám (2007): 125-130.

https://dx.doi.org/10.22503/inftars.VII.2007.3.8

A folyóiratban közölt müvek

a Creative Commons Nevezd meg! - Ne add el! - Így add tovább! 4.0

Nemzetközi Licenc feltételeinek megfelelően használhatók. 


\section{OLVASÁS KÖZBEN}

Danka István

\section{Immobilis ideák vs. mobil kommunikáció}

„A 21. század kommunikációja” címú projekt legújabb kötetéról

Nyíri Kristóf (szerk.): Mobiltársadalomkutatás. Paradigmák-perspektívák. Budapest, Magyar Tudományos Akadémia - T-Mobile, 2007, 167. o.

A mobiltársadalomkutatás (sic!) immáron hétéves múltra visszatekintô diszciplína Magyarországon: Budapest ma a mobil kommunikációs kutatások egyik nemzetközi fellegvára. A honi filozófusok azonban még mindig kételkednek e kutatások értékében. Nem véletlenül: a kommunikációfilozófiai perspektíva outsider filozofálási attitúd; s a mobil kommunikáció végképp az. (Hogyan is lehetne egy kütyüt filozófiai módszerekkel kutatni? - fogalmazódik meg konferenciák kávészüneteiben az obligát buifékérdés.) A filozófusok zöme nem csupán azért fogadja gyanakodva az ilyesfajta témákkal való puszta foglalatoskodást is, mert fennhéjázó bölcsészidentitása miatt nem képes ünnepelni „a 'két kultúra' mítoszának látványos cáfolatát" (9. o.), amit Nyíri Kristóf az előszóban hangsúlyoz, s nem is pusztán azért, mert valami félreértelmezett objektivitásigényból fakadóan megvetendőnek tartja, ha egy kutatási programot nem államilag leosztott pénzekból finanszíroznak. A fó probléma az, hogy „A 21. sæáaad kommunikációja” címú projekt sikerességének vagy akár csak legitimitásának elismerése is a tradicionális filozófia múvelôinek intézményes hátterét és így egzisztenciáját fenyegetné: be kellene látniuk, hogy amit „filozófia” címszó alatt múvelnek, nem más, mint out-of-date légvárépítés.

Nyíri és munkatársai ugyanis nem kevesebbet állítanak, mint hogy a filozófia állítólagos örök problémái az írásbeliségnek köszönhetik a létüket, és az írásbeliségre ráépülő másodlagos szóbeliség - és különösen: a képi gondolkodás - újbóli elôtérbe kerülése a klasszikus filozófia végét fogja jelenteni. Ezért aztán a mobil kommunikáció filozófiájával nem lehet mást kezdeni, mint vagy azonosulni vele, vagy egyszerúen negligálni. Paradigmaváltás zajlik, és az érvek nem képesek áthatolni az egyik paradigmából a másikba. Egy formálódó és képlékenységét önnön differentia specificájaként aposztrofáló hérakleitoszi paradigma csap össze az uralkodó, monolit és immobilis parmenidészivel. A honi mobilkommunikáció-filozófiai kutatási irány (melynek elófutárai Nietzsche, Wittgenstein, Heidegger, az amerikai pragmatikusok és a torontói iskola gondolkodói) a mai általános „hérakleitizálódás” sajátosan magyar - mindazonáltal a magyar és a nyugati filozófia viszonyát történetileg tekintve egyedülállóan úttörố - válfaja. Egyetérthetünk az új iránnyal vagy vitába szállhatunk vele, ám az újdonságát mindenképpen ünnepelnünk illene - ám persze csak fanyalgunk. Nagyon magyar dolog ez.

Ideje tehát fontolóra vennünk: mi is az, ami filozófiailag releváns a mobiltársadalomkutatásban ( $\operatorname{sic} !)$ ? Mivel járulnak hozzá e kutatások ahhoz, ahogyan a világot mint 
egészet látjuk? Ez a kérdés áll a jelen kötet hátterében, amely az eddigi kutatások összegzésére törekszik. A kötet alcíme: „Paradigmák - Perspektívák”; szốrszálhasogatás helyett nagy távlatok felvázolásának igényét sejteti. Tudományoskodás helyett pedig tudományosságra törekvéssel kell szembesülnünk: ahelyett, hogy saját armchair textusainak mélységeit igyekezne feltárni, a mobiltársadalomkutató (sic!) részese igyekszik lenni egy tudományközi dialógusnak, hogy eszmetörténeti jártasságát interdiszciplináris szintézisre használja fel. A filozófiában rejló intellektuális potenciált arra kell szerinte fordítani, amire Platón, Descartes, Kant vagy éppen a rögvest megidézett Hegel fordította: a saját kora problémáinak megragadására. Az ekképp gondolkodó filozófus munkája szükségképpen átfogóbb képet fog nyújtani az iskolafilozófusénál, és éppen azáltal, hogy a tudományos kutatásokra és a mindennapi praxisra is mer hagyatkozni. Ezek után bármivel foglalkozzon is, annak több köze lesz ahhoz, amit magam filozófián értek, mint a mai mainstream áramlatok többségének - legyen az bár egy kütyü; és még inkább így áll a helyzet, ha a kütyünél csak egy kicsit is többról van szó. Személy szerint engem, a mobiltelefonját inkább csak zsebórának használó, a szomszéd szobában ülố kollégával is e-mailben (vagyis írásban) kommunikáló, kábelhez kötve „netezó” és amúgy is gyakran offline, ódivatú, betúzabáló filozófust felettébb bosszantana, ha még életem során bebizonyosodna, hogy Nyíriéknek igazuk van. Ám a kérdéssel nem foglalkozni, a fejünket a homokba dugni és minderre még büszkének is lenni - nos, ez legalábbis felelótlenség.

Persze a mobil kommunikáció kutatásának filozofikus voltát illetốen azért is merülhet fel kétely, mert a korábbi kötetekból többnyire hiányoznak a tradicionális filozófiai témák, s így kérdéses a diszciplináris kontinuitás. Ennek egyik oka az, hogy a projekt filozófus résztvevôinek fố teoretikus bázisa jellemzôen olyan, filozófusként nem kanonizált szerzókön nyugszik, mint a torontói iskola tagjai, illetve annak magyar elófutárai. Sốt, még amikor filozófusokra hivatkoznak is, nem azokra a pontokra helyezik a hangsúlyt, amelyekre a hagyományos filozófia múvelối szokták. Amikor Nyíri Wittgensteinjét vagy Heideggerét olvassuk, nem azok a gondolatok köszönnek vissza, amelyekre iskolák épültek az elmúlt fél évszázadban.

Ám ha részben jogos volt is ez a meglátás az elốzó eredmények kapcsán, a jelen, összegzó kötetrốl feltétlenül elmondható, hogy számos tradicionális filozófiai kérdés is explicit módon megjelenik benne. Pléh Csaba és Bedő Viktor kognitív kérdéseket boncolgató tanulmányai elmefilozófiai szövegek; vérbeli episztemológiát múvel Kondor Zsuzsanna, Golden Dániel és Palló Gábor; no, és nem mehetünk el szó nélkül a teret (András Ferenc) vagy éppen az idốt (Nyíri Kristóf) filozófiailag elemzố dolgozatok mellett sem. Így aztán a filozófiai témájú írások - mondhatni - felülreprezentáltak a jelen kötetben.

Pléh Csaba (Reprezentációs rendszerek, szelekció és gondolati terjedés, 11-19. o.) három tézist állít fel (13. o.): felhívja a figyelmet gondolkodás- és közlésmód szoros kapcsolatára, ezek elemzéséhez analógiákat hív segítségül az evolúciós, egyedfejlódési és kulturális perspektívák köréból, s végül rámutat, hogy az analógiák hátterében oksági kapcsolatok vannak. Pléh célja az analógiákkal az, hogy a már vizsgált evolúciós lépésekre kidolgozott módszertant hívja segítségül, amikor a mostani, illetve majdani változásokról beszél.

A gondolkodás és a nyelv viszonyát taglaló szakasz (16-17. o.) olvasásakor - minek tagadjam - elótört belólem az antireprezentacionista. Pléh persze nem feledkezik meg arról, hogy „[v]annak természetesen olyanok, akik szerint egyáltalán nincsenek reprezentációs viszonyok. Nevezzük ezeket gonosz behavioristáknak” (uo.). A két jelző kö- 
zül a rosszabbat: a behaviorizmus vádját feltétlenül vissza kell utasítanom. Számtalan nem behaviorista módja is lehet a reprezentációs modell elvetésének; akár egyenesen az, hogy a külvilágot magát is normatíve (például hegeliánus módon) írjuk le. Magam inkább wittgensteini/davidsoni alapokon arra hajlanék mégis, hogy azt állítsam: a nyelvi jelenségek egymáshoz való viszonyai elégségesek ahhoz, hogy a nyelv értelmességét magyarázzák, a kommunikáció ténye pedig garantálja, hogy a nyelv embertársainkkal, és így a külvilággal is összeköt bennünket.

Mindenesetre az emlékezeti rendszerek kapcsán Pléh a mobil technológiával kapcsolatos egyik legrosszindulatúbb - és a tanulmány alapján teljesen alaptalan - közhiedelem cáfolatához jut el: az információ mobil hozzáférhetôsége nem a sokat emlegetett globális elhuilyüléshez vezet. A környezetünkbe externált tudásunk révén - akárcsak anno a könyveknek köszönhetốen - „emlékezetünk felszabadul, és további kapacitásokat nyerünk" (18. o.).

Kondor Zsuzsanna (Mobil kép - mobilizált tapasztalat, 21-28. o.) a képek kommunikatív és reprezentatív szerepét vizsgálja. Felhívja a figyelmet arra, hogy „[a]z írásbeliség hosszú évszázadai [...] sajátos gondolattechnikákat hívtak életre, [...] amelyek a vizuális információfeldolgozás eredményét csak részben fedik" (21. o.). Számos mentális képességünk kiaknázatlan marad, ha a képi gondolkodást - amint tettük volt évszázadokon át továbbra is elnyomjuk. A mobiltechnológia pedig - a telefonokba szerelt digitális kamerák és az MMS révén - jelentős lépés afelé, hogy a képi kommunikáció erôsödjék. Kondor szerint „MMS váltása javarészt közeli barátok között, igen szúk körben tapasztalható”, melynek oka az, hogy „egy kép értelmezéséhez közös kontextuális ismeretek megléte szükséges” (23. o.). A szokásos technofób ellenérzéseket cáfolva tehát a mobiltelefon éppen hogy képes „használóját kapcsolataiban mintegy megerősíteni” (uo.).

A tanulmány számomra leginkább megvilágító erejú részében - ahol is a képek immerzív erejéról beszél (25-28. o.) - Kondor olyan következtetésekre jut, amelyek hardcore ismeretelméleti vitákban is komoly relevanciával bírnak. Olybá túnik, Kondor historikus-evolutív perspektívája egyetlen teoretikus keretben képes szintetizálni egy manapság igen divatos, direkt realista álláspontot annak egyik legkomolyabb ellenfelével, a kantianizmussal. Kondor számára ugyanis nem két oppozit pozícióról van szó. Az eredendóen képies gondolkodásunk korában a valósághoz való viszonyunk éppen olyan volt, amilyennek egy direkt realista leírná. A nyelv kialakulásával aztán annak eredetileg kommunikatív funkciójára mindinkább ráépiilt a fogalmi reprezentáció, ami az írásbeliségnek volt köszönhető. Kant korára - akit Kondor név szerint nem említ, de nyilván paradigmatikus alak itt - az értelmiségi elit feje már tényleg tele lehetett a megismerés transzcendentális előfeltételeit képezó intellektuális teherrel, és valóban úgy voltunk képesek csak érzékelni a külvilágot, ha tiszta szemléleti formáinkat a valóságra vonatkoztattuk, majd értelmi fogalmaink alá szubszumáltuk az érzéki sokaságot. Kondor perspektívájából alátekintve e skolasztikus vita még meddóbbnek túnik, mint valaha: ha kantiánusok szeretnénk maradni, olvassunk jó vaskos könyveket, s ha újra direkt realistákká akarunk válni, egyszerúen váltsunk több MMS-t szeretteinkkel.

Benedek András (Mobil tanulás és az egész életen át megszerezhetố tudás, 29-37. o.) az élethosszig tartó tanulás és a mobil tanulás oktatáselméleti kérdéseit joggal kapcsolja össze. Arra a következtetésre jut, hogy „[a]z internet és a mobiltelefonok világa félreismerhetetlenül egyfajta szerves tanulási környezetté válik” (34. o.), s „[a] kor egyik peda- 
gógiai ellentmondása, hogy e változások ellenére a gondolkodás, a tanulás és a kommunikáció továbbra is az osztályteremben elhangzó szavak világában zajlik" (35. o.).

A mobilmunka jelenségére hívja fel a figyelmet Maradi István (Mobilmunka, 39-49. o.), utalva arra, hogy a mobilitás nem feltétlenül jelent mobiltelefonon végzendő munkát. A mobilmunka nem, illetve nem teljesen helyhez kötött; nagy részben otthon vagy útközben is végezhetô. Mindazonáltal ,a hely továbbra is rendkívül fontos szerepet játszik a mobilmunkás életében" (40. o.).

Kovács Kristóf (A modern technológia szerepe az IQ generációk közti növekedésében, 51-60. o.) az intelligenciahányados generációk között nemzetközi viszonylatban mérhetô mértékû növekedéséról számol be, ismét csak cáfolva a közvélekedést, hogy az elektronikus média korában az emberiség elhülyül. A számos magyarázó hipotézis között - azokat nem riválisokként, sokkal inkább egymás kiegészítóiként láttatva - hangsúlyozza az elektronikus média szerepét, ami fóleg a vizuális/ikonikus jellegú feladatok megoldására gyakorolt, természetesen pozitív hatásban érhetố tetten.

Sándor Klára (Vissza a természeteshez, 63-71. o.) nyelvészként azt a kérdést vizsgálja, hogy „rontja-e a mobiltelefon a nyelvet” (63. o.). Válasza filozofikusan terapeutikus: a kérdés elhibázott, mert feltételezi, hogy van olyasfajta változhatatlan entitás, mint a „jơ” nyelv, amely elrontható - s persze e változhatatlanság mítoszát az írásbeliség számlájára írhatjuk. Miközben említ számos nyelvi változást, amelyek a szóbeliség jegyeit magán viselő, jóllehet írott SMS használatából fakadnak, kiemeli, hogy „[a] mobilkommunikációval kapcsolatos félelmek valójában a szóbeliségtól való félelmek" (66. o.), pedig a mobil által „az a kommunikációs közeg tér vissza, amely az ember számára a legtermészetesebb" (67. o.).

Golden Dániel (Mobilizált észlelés, 73-81. o.) a mobiltelefont egyfajta protézisként fogja fel, azt az általánosabb hipotézisét is példázandó, hogy „,[a]z emberi képességek vélt vagy valós fogyatékosságainak kiküszöbölése egyike a technológiai fejlődés legfóbb motorjainak" (74. o.) - tehát mobiltelefonra azért van szükségünk, mert nem hallunk kellóen messzire. A mobil „kitágítja az ember természetes észlelési környezetét” (75. o.), ezáltal fizikai kapcsolataink meghosszabbítását eredményezi (79. o.). Goen szerint azonban a kommunikációfilozófiai paradigma nem alkalmazható maradéktalanul a mobil percepció elméletére: „nem az érzékletek közvetlen megosztásáról van itt szó” (81. o.), és bár „a tudást érintố változások [...] nem annyira az episztemológia, mint inkább a tudásszociológia szótárával írhatóak le”, a mobil észlelés tapasztalás, nem tudás, s így nem társas (uo.).

András Ferenc (A tér mint kommunikációs színhely, 83-90. o.) szerint a „térról mint kommunikációs színhelyról” való beszédhez szükséges minimális elkötelezódés a „kommunikációs szereplók elkülönítése” lesz (86. o.), azaz a kommunikációs tér elófeltételezi a fizikai teret. András az „eg̉yidejúség mítoszaként” emlegeti azt a vélekedést, amely negligálja, hogy az információhoz való hozzáféréshez szükséges „időigény sohasem csökkenhet nullára" (87. o.), így a fizikai tér szerepe elvileg redukálhatatlan a kommunikációs térról alkotott magyarázatainkból.

Nyíri Kristóf legújabb, az idő természetére irányuló kutatásaiba nyújt bepillantást (Idő és mobilrend, 91-100. o.). Az idôtematika filozófiai jelentôsége vitathatatlan; talán a mobilkommunikáció relevanciája vár indoklást: a mobiltelefon egyrészt mint óra, másrészt mint koordinációs és idốorganizációs eszköz jelenik itt meg. 
Nyíri amellett érvel, hogy a mobil korban „nemcsak az idôról való beszédünk változott meg, sốt nem is csupán az időélményünk. Ami megváltozott, az az idố természete maga" (91. o.). Így aztán elsősorban a szubjektivista/konstruktivista idôfelfogások képviselóihez képest pozicionálja saját álláspontját - egy objektivista időszemlélet nyilván nem engedné meg, hogy társadalmi változások befolyással lehetnek az idő természetére. Bergsonnál elidốzve arra jut, hogy az idô voltaképp tartam (95. o.), amely elképzelés egyébként összhangba hozható lenne egyes kortárs eseményontológiákkal. Heideggerrel leszögezi, hogy „lenni annyit jelent, mint idóben lenni” (uo.), s Wittgensteinnel hangsúlyozza, hogy nincs olyan dolog, mint az idő, csak az idôról való beszédmód szüli az efféle félreértéseket (96-97. o.).

Saját idôfelfogását vázolandó Sellars szellemét idézi meg; az idốt ennek alapján mint teoretikus entitást, vagyis társadalmi konstrukciót láttatja. Nyíri tehát konstruktivista, de nem antirealista az idő tekintetében: idő van, de csak amennyiben létrehoztuk. S éppen ez teszi lehetốvé, hogy a társadalmi változások az idô természetében is változásokat generáljanak. A mobilkoordináció eredménye Nyíri szerint a „személyre szabott idố élménye" (99. o.) lesz.

Szvetelszky Zsuzsanna (Mobilkommunikáció, önszervezódés és városrehabilitáció, 101108. o.) emlékeztet a projekt egy korábbi eredményére, miszerint „a multimédiális mobilkommunikáció nemcsak a globális tájékozódást teszi hatékonyabbá, de a helyi kötődéseket is erôsíti” (103. o.). A „mobilkommunikációban rejlő közösségépítố lehetôségeket” (101. o.) tárgyalva arra jut, hogy a mobil lokatív információ a „tudatos városhasználatot" (107. o.) fokozhatja. Ennek lényeges mozzanata a mobil elektronikus térkép, melyról Bedő Viktor ejt több szót (Térképek mint gondolkodásunk eszközei, 109118. o.). Bedố a mobil gyakorlati tudás helyérzékeny aspektusaira hívja fel a figyelmet, a vizuális mintázatok gondolkodásunkban betöltött szerepére mutatva rá.

Prazsák Gergó pedig (Network Society 2.0, virtuelle Gemeinschaft, 119-130. o.) az empirikus szociálpszichológia és a gráfelmélet/hálózatelmélet szintézisére alapozva körvonalazza az újabb típusú „behálózott társadalom” kutatásának néhány lehetséges témáját.

Dányi Endre (Az internet és a mobiltelefon mint versengó metaforák, 133-141. o.) a mobiltelefon és az internet politikai kommunikációban betöltött szerepéról ír. Az internet mint „a teljes új médiakörnyezet” (136. o.) víziójával szemben - a mobiltelefon politikai kommunikációban betöltött szerepére utalva - a médiumok közötti kapcsolatokat hangsúlyozza (139. o.), míg Schneider Henrik (A tudósitó mobil. Új platform a civil médiában, 143-151. o.) a mobiltelefonnak a médiában betöltött szerepére, alkalmazásának eloónyeire és korlátaira mutat rá, nem feledkezve meg arról a kérdésról sem, hogy a mobil használata vajon befolyásolja-e a megfigyelt eseményt (150. o.) - jóllehet a kommunikációs közegból adódó zaj problémája nem mobilspecifikus; a mobil kommunikáció elviekben semmivel sem torzít jobban, mint bármely más típusú kommunikáció.

Palló Gábor (Tanúság, képek és a tudomány hihetósége a mobilidószakban, 153-161. o.) kérdése az, hogy „érintetlenül marad-e a tudományos állítások igazsága a digitális képek használatakor" (154. o.). Ez a társas episztemológia területére vezet, amely szerint „ismereteink többségét nem saját tapasztalatainkból szerezzük, hanem más emberektốl” (155. o.). Ezen tudásszerzési formát nevezzük tanúságnak, „melyet a mobiltelefon ragyogóan kiszolgál" (uo.). Palló kiemeli a képek mint jusztifikációs eszközök szerepét: 
„a képeknek ugyanolyan ismeretelméleti értéke lehet, mint a tapasztalatnak vagy az emlékezetnek" (158. o.). A digitális képalkotás elósegíti a pontosabb képi reprezentációt, valamint a hamisításnak (és a hamisítás kiszúrésének) a lehetôségét is. Palló tehát joggal vonja le a következtetést, hogy a multimediális mobiltelefon komoly ismeretelméleti szerepet játszik a tudományban (161. o.).

Az amúgy laptop mellé becsúsztatható, karcsú kötet - az előszóval együtt - mintegy tizenhat tanulmányt tartalmaz, így kb. tíz oldal jut egy-egy munkára. Ez nagyon jót tesz az olvashatóságnak. Különösen fontos ez azért, mert a téma iránt érdeklődók bizonyos hányada feltehetóleg - ugyanúgy, mint jómagam - nem szeret papírral túl sokat szemezni; ha csak teheti, LCD-n olvas; gyúlöl - kulcsszavas keresés helyett - visszalapozgatni; bosszantja, hogy böngészố - és így csúszka - híján nem látja, éppen hol tart a szövegben; értetlenkedik, miért neki kell a linkeket belefirkálnia a szövegbe, hogy összefüggéseket tárjon fel a bekezdések között; és eleve fárasztja a szemét a vakító, hófehér papíron lévớ, éles kontrasztú betúk olvasása. S ha már betúk: szintén az olvasást könnyíti, hogy a szöveg viszonylag nagy méretú, talpatlan betúkkel van szedve. Amit e tekintetben hiányolok, az a tanulmányokban annyit hangsúlyozott képek: valamelyes multimedialitás határozottabb megjelenése.

Az írások közötti tematikus átfedések, illetve az elốzó kötetekben közölt, közösen használt textuális bázis azt mutatja, valóban alakulóban van az a diszciplína, amelyet múvelói „mobiltársadalomkutatásnak” kereszteltek el. S az egyes tanulmányokat olvasva az is kiderül, hogy ha némiképp lassabban is, mint az empirikus tudományos vizsgálódás, a filozófiai reflexió is kezd olyan mélységú lenni a mobilkutatás vonatkozásában, hogy megfelelhet a társadalmi kihívásoknak és szakmai kívánalmaknak.

A mobiltelefon jövóbeli társadalmi hatásai persze kérdésesek, ám hogy hatásai lesznek, mert már vannak, az immár nem pusztán mindennapi tapasztalat, de tudományos tény. S hogy a filozófusközösség komolyan vegye a mobilkommunikáció gerjesztette fogalmi problémákat, az nemcsak a mobilhasználók, hanem éppúgy a filozófusok érdeke is. 